\title{
Ecotoxicological quality in sediments of Reloncaví and Corcovado gulfs, Chile
}

\author{
Anny Rudolph ${ }^{1}$, Gabriela Aguirre ${ }^{1}$, Julio Moscoso ${ }^{1}$, Nelson Silva ${ }^{2}$ \& Ramón Ahumada ${ }^{1}$ \\ ${ }^{1}$ Departamento de Química Ambiental, Universidad Católica de la Santísima Concepción \\ Casilla 297, Concepción, Chile \\ ${ }^{2}$ Escuela de Ciencias del Mar, Pontificia Universidad Católica de Valparaíso, Valparaíso, Chile
}

\begin{abstract}
A study of the ecotoxicological quality of surface sediment was carried out on samples collected in the main fjords and interior channels between Reloncaví and Corcovado gulfs. The surface sediment samples were taken with a box corer and analyzed for organic matter content and grain size. Dissolved oxygen was measured in water samples taken $10 \mathrm{~m}$ off the bottom. The ecotoxicological evaluation of the sediments was performed using fertilization assays with gametes of Arbacia spatuligera (EPA/600/4-91/003). A fertilization rate of 95\%, similar to that of the controls, was achieved. Therefore, the sediments at the sampled stations located in the middle of the channels were classified as nontoxic. Only the sediment at Station 26 (i.e., sector Dalcahue) was classified as "slightly toxic" $(90 \pm 4.1 \%)$. The samples were taken from the central zones of the studied channels and fjords. Since toxicologically these central areas are not polluted, any possible effects of aquaculture activities are expected to be more local in scope.
\end{abstract}

Key words: sediment quality, fertilization assays, pollution, aquaculture, southern Chile.

\section{Calidad ecotoxicológica de los sedimentos entre los golfos Reloncaví y Corcovado, Chile}

RESUMEN. Mediante el análisis de muestras de sedimento superficial, tomadas en los principales fiordos y canales interiores entre el golfo de Reloncaví y golfo Corcovado, se realiza el estudio de su calidad ecotoxicologica. Las muestras superficiales de sedimentos se obtuvieron con un box corer. Se analizó el contenido de materia orgánica y textura de los sedimentos, y oxígeno en la columna de agua disuelto de muestras de agua tomadas a 10 m del fondo. Además, se realizó la evaluación ecotoxicológica de los sedimentos mediante pruebas de fecundación con gametos de Arbacia spatuligera (EPA/600/4-91/003), resultados que indican que sobre el 95\% de ovas fueron fecundadas, valor semejante a los controles, lo que permite clasificar a los sedimentos de las estaciones ubicadas en el centro de los canales como no tóxicos. Sólo el sedimento de la estación 26 (i.e., sector Dalcahue) mostró un $90 \pm 4,1 \%$, lo que se clasificaría como sedimento "levemente tóxico". Las muestras fueron recolectadas en las zonas centrales de los canales y fiordos muestreados. Se concluye que estas zonas, desde el punto de vista toxicológico, no están contaminadas por lo que se estimó que un posible efecto de las actividades de la acuicultura sería más localizado.

Palabras clave: calidad de sedimentos, ensayos de fecundación, contaminación, acuicultura, zona austral, Chile.

Corresponding author: Anny Rudolph (annyr@ucsc.cl) 


\section{INTRODUCTION}

The marine sediments are an environmental matrix (Elderfield, 1978) in which the stratigraphic disposition conforms a record of the processes and balances that occur in the surface layers (Stumm \& Morgan, 1981; Colombo et al., 1996). The chemical composition of the sediment depends on the mineralogical constitution of the mother rocks that originate it; the grain size, composition, and chemical characteristics of the environment in which it is deposited; the advective processes of the site; and anthropogenic contributions (Ahumada, 1998).

If the fraction of the natural or anthropogenic material that is input into an aquatic system is "trapped" in the sediments - and depending on its chemical quality - it can alter and/or change the substrate composition and may leave a record of such activity in the sediment column. In order for such a change to be recorded, it must be of a certain magnitude, persist over time, and occur in the absence of physical or biological disturbances (Ahumada, 1998). An analysis of critical variables (i.e., organic matter content, molecular markers) per strata in this matrix can show the history of the recent changes (Ponce-Velez \& Botello, 1991), revealing the average production at a site and/or additional input generated by the use of the coastal area.

Non-specific toxicity assays offer one way to study the quality of recent sediments (Cairns \& Pratt, 1989; Chapman, 1995). Such tests use the first centimeters of the surface sediment. Generally, chemical analyses of individual toxic compounds are not sufficient for inferring the potential ecological risk of a possibly polluted matrix since they do not allow evaluations of the combined action of all the chemical compounds present in the sediment at a given site, including their bio-availability (Chou et al., 2003). Toxicity assays, on the other hand, integrate these effects, making this the recommended methodology for evaluating risks in areas adjacent to or near possible pollution sources. Moreover, these assays can be used as an early warning system to indicate changes in aquatic environments; they can be performed quickly and are useful for evaluating the effectiveness of implemented mitigation measures (Wong et al., 1999).

Given the advantages of analyzing the sediments as an environmental matrix (i.e., a historical record), a wide variety of toxicological tests has been developed. These tests range from evaluations of measurements of lethal and sub-lethal responses to estimates of alterations in the structure and functioning of benthic communities (Duffus, 1983; Van Gestel et al., 2001).

The last decade has seen a greater emphasis on toxicity tests using the more sensitive life stages of organisms, including, for example, procedures with amphipods, sea urchins, and polychaetes (KastHutchenson et al., 2001; Amin \& Comoglio, 2002). Fertilization tests with Arbacia punctulata gametes (EPA/600/4-91/003) have been standardized by USEPA (1988) as a type of non-specific toxicity assay. Excellent results have been achieved in Chile with the species A. spatuligera, which is easy to manipulate and whose analysis requires little time (Riveros et al., 1996; Larraín et al., 1999; Arévalo et al., 2001). Knowledge on the biology of the species (i.e., feeding regimen studies, availability, acclimatization) has been furthered (Silva et al., 2004).

Most of the country's aquaculture centers are found in the channels and fjords between Puerto Montt and the Boca del Guafo, placing a heavy demand on this coastline. For example, 74 farming centers were registered in 1995 whereas, in 2003, 267 fish farms, 254 shellfish farms, and 273 algae farms were registered (SERNAPESCA, 2004).

Fish farming requires the artificial feeding of a large amount of fish. This, in turn, generates organic waste (fecal fish pellet, uneaten food) that is deposited on the sediment (Buchmann, 2005). A series of chemical compounds (i.e., antibiotics) used to avoid diseases in the farmed species are also added to the mix along with those agents used to limit the adherence of undesirable organisms to the facilities (i.e., antifoulings) (Alvial, 1993; Kelly et al., 1996, Buschmann, 2005). Some of these compounds are absorbed by particulate organic matter so that, when this sediments, the compounds are also carried to the bottom (Chou et al., 2003).

The objective of this study was to carry out standardized, high sensitivity toxicity assays (i.e., fertilization tests with gametes of Arbacia spatuligera) in order to analyze the toxic quality of the sediments in some fjords and channels from Puerto Montt to Boca del Guafo.

\section{MATERIALS AND METHODS}

Sediment sampling was done during the CIMAR 10 Fiordos cruise between 17 August and 6 September 
2004, on board the oceanographic vessel AGOR "Vidal Gormaz". Samples were taken at three stations in each of the seven sections of the study area between Puerto Montt $\left(41.5^{\circ}\right)$ and Boca del Guafo $\left(43^{\circ} \mathrm{S}\right)$ (Fig. 1; Table 1).

The same stations were used for water column dissolved oxygen samples. These were taken at standard depths and up to $10 \mathrm{~m}$ from the bottom with Niskin bottles attached to a rosette. Dissolved oxygen was determined according to the Winkler method as modified by Carpenter (1965).

The sediment samples were extracted with a box corer and three replicates were taken of the first three $\mathrm{cm}$ of the sediment. The samples were stored in polyethylene containers, labeled, and frozen at $-20^{\circ} \mathrm{C}$ for later organic matter, grain size, and toxicology analyses.

The organic matter content in the sediments was determined gravimetrically using the technique of weight loss on ignition (Byers et al., 1978). The grain size (granulometry) was determined according to the Udden-Wenthworth classification through wet sieving.
The toxicity tests of the sediment were performed following the specifications of the method EPA/600/4-91/003 (USEPA, 1988) and modifications introduced by Zúñiga (1999). Basically, this method consists of producing an artificial fertilization using spermatozoids exposed for $60 \mathrm{~min}$ to an elutriate prepared with the sediment being studied; the fertilization is then compared with positive and negative controls that are performed simultaneously. The elutriate was obtained through the Dinnel \& Strober (1985) methodology, that is, by agitating 50 $\mathrm{g}$ of sediment in a Heidolph Unimax 2010 at $5 \mathrm{rpm}$ with $50 \mathrm{~mL}$ of filtered, aerated seawater for $10 \mathrm{~min}$; this was later left in the cold $\left(4^{\circ} \mathrm{C}\right)$ for $12 \mathrm{~h}$ to separate the liquid phase (elutriate) from the sediment.

For the sea urchin test, specimens were collected by scuba divers in an area with low anthropogenic impact. The sea urchins were acclimated for a week at $13 \pm 2^{\circ} \mathrm{C}$ in 120 -L glass aquariums with daily water changes, constant aeration, and food. The gametes were obtained by injecting a $\mathrm{KCl} 0.5 \mathrm{M}$ solution into the perivisceral region of each specimen; these were used to prepare spermatic solutions of $7 \cdot 10^{7}$ sperm. $\mathrm{mL}^{-1}$ and $2 \cdot 10^{3}$ eggs $\cdot \mathrm{mL}^{-1}$.

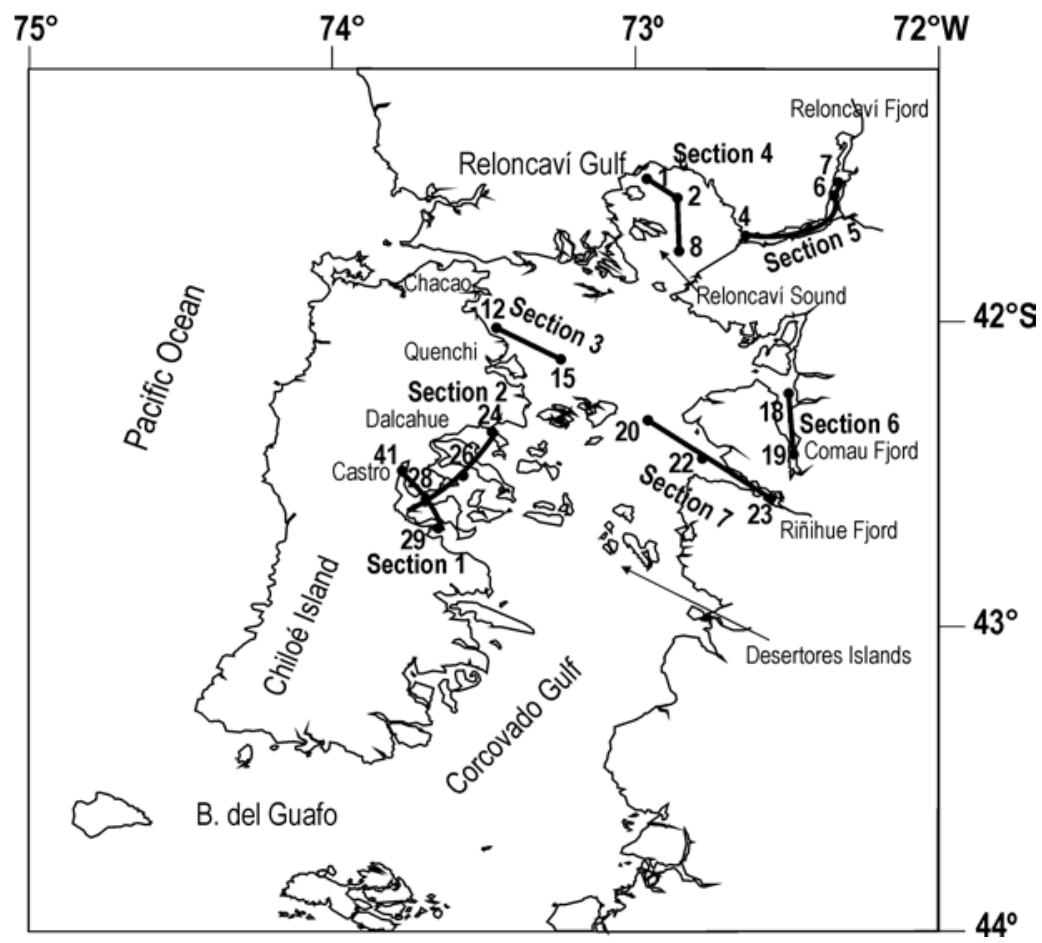

Figure 1. Study area, to indicate location of sections and sampling stations analyzed during CIMAR 10 Fiordos Cruise (August-September 2004). 
Table 1. Geographical position, depth, water column dissolved oxygen, saturation percentage near the bottom $(\approx 10 \mathrm{~m})$, and sediment organic matter registered on CIMAR 10 Fiordos Cruise, 2004.

\begin{tabular}{|c|c|c|c|c|c|c|}
\hline Station & $\begin{array}{c}\text { Latitude } \\
\text { (S) }\end{array}$ & $\begin{array}{c}\text { Longitude } \\
\text { (W) }\end{array}$ & $\begin{array}{c}\text { Depth } \\
\text { (m) }\end{array}$ & $\begin{array}{c}\text { Sediment organic } \\
\text { matter } \\
(\%)\end{array}$ & $\begin{array}{l}\text { Dissolved } \\
\text { oxygen } \\
\left(\mathrm{mL} \cdot \mathrm{L}^{-1}\right)\end{array}$ & Saturation \% \\
\hline \multicolumn{7}{|c|}{ Section 1 Castro } \\
\hline Sta. 41 & $42^{\circ} 24.92$ & $73^{\circ} 44.54$ & 18 & 5.87 & 5.61 & 88.2 \\
\hline Sta. 28 & $42^{\circ} 34.92$ & $73^{\circ} 44.64$ & 60 & 3.32 & 5.84 & 91.49 \\
\hline Sta. 29 & $42^{\circ} 43.02$ & $73^{\circ} 35.52$ & 145 & 5.39 & 5.82 & 91.32 \\
\hline \multicolumn{7}{|c|}{ Section 2 Dalcahue } \\
\hline Sta. 24 & $42^{\circ} 21.42$ & $73^{\circ} 29.58$ & 108 & 5.22 & 5.77 & 90.6 \\
\hline Sta. 26 & $42^{\circ} 30.06$ & $73^{\circ} 33.42$ & 72 & 1.56 & 5.98 & 98.8 \\
\hline Sta. 28 & $42^{\circ} 34.92$ & $73^{\circ} 44.64$ & 60 & 3.32 & 5.84 & 91.5 \\
\hline \multicolumn{7}{|c|}{ Section 3 Chacao } \\
\hline Sta. 11 & - & - & - & Rocky bottom & - & - \\
\hline Sta. 12 & $41^{\circ} 59.04$ & $73^{\circ} 28.14$ & 138 & 2.19 & 5.38 & 85.2 \\
\hline Sta. 15 & $42^{\circ} 06.24$ & $73^{\circ} 14.94$ & 192 & 7.05 & 5.18 & 91.5 \\
\hline \multicolumn{7}{|c|}{ Section 4 Reloncaví Sound } \\
\hline Sta. 1 & $41^{\circ} 31.44$ & $72^{\circ} 55.55$ & 285 & 8.64 & 3.95 & 48.1 \\
\hline Sta. 2 & $41^{\circ} 37.26$ & $72^{\circ} 50.52$ & 298 & 6.16 & 3.87 & 61.8 \\
\hline Sta. 8 & $41^{\circ} 45.12$ & $72^{\circ} 50.28$ & 207 & 2.95 & 3.88 & 62.3 \\
\hline \multicolumn{7}{|c|}{ Section 5 Reloncaví Fjord } \\
\hline Sta. 7 & $41^{\circ} 33.00$ & $72^{\circ} 20.04$ & 496 & 6.04 & 2.99 & 48.1 \\
\hline Sta. 6 & $41^{\circ} 35.52$ & $72^{\circ} 20.46$ & 155 & 6.49 & 2.73 & 43.9 \\
\hline Sta. 4 & $41^{\circ} 43.02$ & $72^{\circ} 36.96$ & 452 & 5.2 & 3.69 & 67.4 \\
\hline \multicolumn{7}{|c|}{ Section 6 Comau Fjord } \\
\hline Sta. 17 & $42^{\circ} 08.45$ & $72^{\circ} 45.08$ & 363 & 6.37 & 3.60 & - \\
\hline Sta. 18 & $42^{\circ} 13.87$ & $72^{\circ} 29.80$ & 475 & 7.49 & 3.63 & 58.6 \\
\hline Sta. 19 & $42^{\circ} 26.64$ & $72^{\circ} 26.10$ & 80 & 7.28 & 3.96 & 63.5 \\
\hline \multicolumn{7}{|c|}{ Section 7 Riñihue Fjord } \\
\hline Sta. 20 & $42^{\circ} 26.64$ & $72^{\circ} 26.10$ & 238 & 7.28 & 5.29 & - \\
\hline Sta. 22 & $42^{\circ} 27.00$ & $72^{\circ} 45.30$ & 257 & 7.85 & 5.05 & 80.2 \\
\hline Sta. 23 & $42^{\circ} 32.70$ & $72^{\circ} 34.98$ & 254 & 3.89 & 4.65 & 74.5 \\
\hline
\end{tabular}

The experimental procedure consisted of preparing three series of tubes with: $5 \mathrm{~mL}$ of sediment elutriate from the sea urchin extraction site (i.e., negative control), $5 \mathrm{~mL}$ of increasing concentrations of copper sulfate between 3.6 and $100 \mu \mathrm{g} \cdot \mathrm{L}^{-1}$ (i.e., positive control), and $5 \mathrm{~mL}$ of sediment elutriate from the study area. The sperm suspension (100 $\mu \mathrm{L}$ ) was added to each of these series and then incubated for one hour at $13 \pm 2^{\circ} \mathrm{C}$. After this, $1 \mathrm{~mL}$ of the egg solution was added and the tubes were again incubated for $15 \mathrm{~min}$, during which time the fertilization took place. The assay was ended by adding
$1 \mathrm{~mL}$ formaline at $10 \%$. One hundred eggs were counted under a microscope (100X magnification) and the fertilized eggs, identified by the fertilization membrane, were expressed as a percentage.

The sensitivity of the toxicity assay was evaluated in function of the positive and negative controls through the application of the statistical package TOXSTAT (Gulley et al., 1988). The $\mathrm{EC}_{50}$ was calculated through the probit method (Finney, 1971). Normality was analyzed with the Shapiro-Wilk test and the homogeneity of variance of the data with the Bartlett test. Later, the parametric Dunnett test 
was used to compare the percentages of fertilization for the sediment samples with respect to the controls (statistical package Statistica version 6.0, StatSoft. Inc; 2001).

\section{RESULTS}

The sampling carried out in the central sectors of the analyzed fjords and channels used shallow stations of around $18 \mathrm{~m}$ depth and deep stations up to $496 \mathrm{~m}$ (Fig. 1). The location of the sections, the sampling depths, and the results of the chemical characteristics of the sediment and near-bottom water at each station are presented in Table 1. The sections at Reloncaví Sound, Reloncaví and Comau fjords had the lowest near-bottom oxygen concentrations, with saturation values between 43.8 and 98.8\% (Table 1).

The toxicity assays with the elutriate of the sediment samples presented fertilization percentages similar to the negative control, i.e., >95\% (Table 2). Station 26 (section 2, sector Dalcahue) was an exception; there, the fertilization percentage was 90.0 \pm 4 .1. This 72 -m-deep station had low organic matter content in the sediment (i.e., 1.56\%) and high oxygen throughout the water column $\left(>5 \mathrm{~mL} \cdot \mathrm{L}^{-1}\right)$, which does not explain the low percentages of fertilization success observed in this sector.

\section{DISCUSSION}

The particulate organic matter input into the ocean, for example through sewage emissions or, as in this study, from fish feeding activities in aquaculture, accumulates in the sediments, although not necessarily constituting a toxic component. Nonetheless, its accumulation and oxidative processes produce changes in the dissolved oxygen content of the interstitial water and in the overlying water column, also altering sediment grain size, absorption of chemical species, and the distribution of benthic species sensitive to the lack of dissolved oxygen. It is possible that suboxic conditions generate an additional stress on the toxic effect of the sediment components. Thus, the toxicity of the sediments depends on numerous factors and not only on the suboxia or anoxia associated with the substrate. Such an alteration is referred to as "non-specific toxicity".

According to Silva et al. (1997), Silva \& Calvete (2002), and Valdenegro \& Silva (2003), none of
Table 2. Percentages of fertilization using sediment elutriates in fertilization assays with gametes from Arbacia spatuligera, evaluated by section in the study area $(\mathbf{n}=8)$.

\begin{tabular}{|c|c|c|}
\hline Station & $\begin{array}{c}\text { Percentage of } \\
\text { fertilization }\end{array}$ & $\begin{array}{l}\text { Standard } \\
\text { deviation }\end{array}$ \\
\hline \multicolumn{3}{|c|}{ Section 1 Castro } \\
\hline Sta. 41 & 98.75 & 1.83 \\
\hline Sta. 28 & 98.75 & 1.28 \\
\hline Sta. 29 & 99.0 & 1.81 \\
\hline \multicolumn{3}{|c|}{ Section 2 Dalcahue } \\
\hline Sta. 24 & 99.50 & 0.93 \\
\hline Sta. 26 & 90.00 & 4.14 \\
\hline Sta. 28 & 98.75 & 1.28 \\
\hline \multicolumn{3}{|c|}{ Section 3 Chacao - Quemchi } \\
\hline Sta. 11 & - & - \\
\hline Sta. 12 & 99.0 & 2.14 \\
\hline Sta. 15 & 98.25 & 2.43 \\
\hline \multicolumn{3}{|c|}{ Section 4 Reloncaví Sound } \\
\hline Sta. 1 & 96.75 & 1.03 \\
\hline Sta. 2 & 97.38 & 3.54 \\
\hline Sta. 8 & 99.0 & 0.98 \\
\hline \multicolumn{3}{|c|}{ Section 5 Reloncaví Fjord } \\
\hline Sta. 7 & 99.0 & 1.77 \\
\hline Sta. 6 & 97.88 & 2.03 \\
\hline Sta. 4 & 94.75 & 2.38 \\
\hline \multicolumn{3}{|c|}{ Section 6 Comau Fjord } \\
\hline Sta. 17 & - & - \\
\hline Sta. 18 & 98.75 & 1.83 \\
\hline Sta. 19 & 99.12 & 1.46 \\
\hline \multicolumn{3}{|c|}{ Section 7 Riñihue Fjord } \\
\hline Sta. 20 & 100 & 0 \\
\hline Sta. 22 & 98.25 & 2.92 \\
\hline Sta. 23 & 99.88 & 0.35 \\
\hline
\end{tabular}

the fjords or channels in southern Chile presents an anoxic water column. These authors only observed suboxic conditions $\left(1.5-3 \mathrm{~mL} \cdot \mathrm{L}^{-1}\right)$ in the deep areas at the heads of most of the channels and fjords along the continental edge. For Reloncaví Sound (section 4), Reloncaví Fjord (section 5), and Comau Fjord (section 6), the lowest values of dissolved oxygen fluctuated between 2.73 and $3.96 \mathrm{~mL} \cdot \mathrm{L}^{-1}$ in the deep basins $(>250 \mathrm{~m})$ and these did not necessarily present the greatest percentages of organic matter (Table 2). Oxygen in the surface waters was always near the saturation level (90-110\%). Silva et al. (1998a) found that, to the north of Boca del Guafo, the low dissolved oxygen contents observed in the bottom samples taken from deep channels and fjords were due to restricted circulation caused by topographic effects, specifically shallow sills and constrictions generated by groups of islands (e.g., the Desertores 
Islands). Furthermore, the contribution of organic matter from the more productive estuarine areas should be considered.

The low concentrations of dissolved oxygen in these channels were detected in the early 1970s during the oceanographic cruise Hudson 70 (NODC, 1994), which was performed nearly 15 years prior to the inception of large marine farming companies. Hence, in spite of the current low concentrations of dissolved oxygen in the study area $\left(2-3 \mathrm{~mL} \mathrm{O}_{2} \cdot \mathrm{L}^{-1}\right)$, it is possible to sustain a diversity of benthic life in the sediment (Clavert et al., 1996; Hagerman et al., 1996).

The organic matter content fluctuated between 2.95 and $8.64 \%$, with a total average of $5.88 \pm 1.88$ and a coefficient of variation (CV) of $32 \%$ for an $\mathrm{n}=20$. However, when the values lower than $4 \%$ were eliminated, the organic matter averaged 6.90 \pm 0.92 with a CV of $13.27 \%(n=14)$. This average value is similar to the base line concentration for the microbasins in this zone and to that reported for cruises carried out in 1995 (Silva et al., 1998b). The sediments in this area have average organic matter values as compared with the semi-enclosed areas of the highly productive Chilean coast such as Concepción Bay (i.e., 12-18\% organic matter) (Rudolph et al., 2002) and with areas that maintain a high exchange with the adjacent oceanic zone such as Corcovado Gulf (i.e., 1-2\% organic matter) (Silva et al., 1998b; Silva \& Prego, 2002).

Concentrations of organic matter over $10 \%$ require large amounts of dissolved oxygen, thereby decreasing the concentrations in the water overlying the sediment and generating a reducing environment that favors the formation of organic macromolecules, with a great affinity for trace metals (chelation) and xenobiotics (absorption) (Birch et al., 2001; Lopes \& Furlong, 2001; Hites et al., 2004; Monteiro \& Roychoudhury, 2005).
When chemical compounds are deposited on the sediments, their elutriates release soluble chemical species (organic and/or inorganic) when the oxidation conditions of the water column change; these chemical species can form potential toxins for organisms. Toxicity tests were performed with the sediments from different basins in the fjords and channels in which marine farming facilities are located in order to establish the sedimentary condition or degree of toxicity.

The toxicity assays showed high percentages of fertilization, implying that the sediments in the studied areas do not contain concentrations of chemical compounds that impede fertilization according to the tests performed (Table 2). The evaluation criteria used to determine the sediment quality in function of the fertilization percentage of A. spatuligera gametes (Table 3 ) revealed "non-toxic" sediments that behaved similarly to the control (i.e., 95-100\% fertilization). Only the sediments at Station 26 (section 2) had lower fertilization rates $(90 \pm 4.1 \% ; n=$ 8 ) indicating toxicity; the sediments at this site were classified as "slightly toxic" (Table 3 ).

The information on the toxicological quality of the sediments in the study area was compared with the work of Aguirre (2004), who studied bay and port sediments along the Chilean coastline using the same methodology to determine toxicity and with similar assay sensitivity. The comparison suggests that the sediment in the middle of the analyzed channels and fjords corresponds to a non-toxic or low alteration zone (Fig. 2), similar to the sediments in Coliumo, an area subjected to minimal alteration (Fuentes-Ríos et al., 2005; Altamirano-Chovar et al., 2006). Nevertheless, this evaluation was based on one type of toxicity assay: the fertilization of sea urchin gametes. In order to accept or reject a working hypothesis that implies a possible alteration produced by aquaculture activities, future research

Table 3. Quality criteria of sediment as a function of the percentage of fertilization obtained using the Arbacia spatuligera gamete assay (Aguirre, 2004).

\begin{tabular}{lcc}
\hline Scale & Quality criteria (\% success in the fertilization) & Characteristic \\
\hline 1 & $100-95$ & No toxic, behavior of the controls \\
2 & $94-85$ & Slightly toxic \\
3 & $84-75$ & Toxic \\
4 & $74-55$ & Very toxic \\
5 & $<54$ & Polluted \\
\hline
\end{tabular}




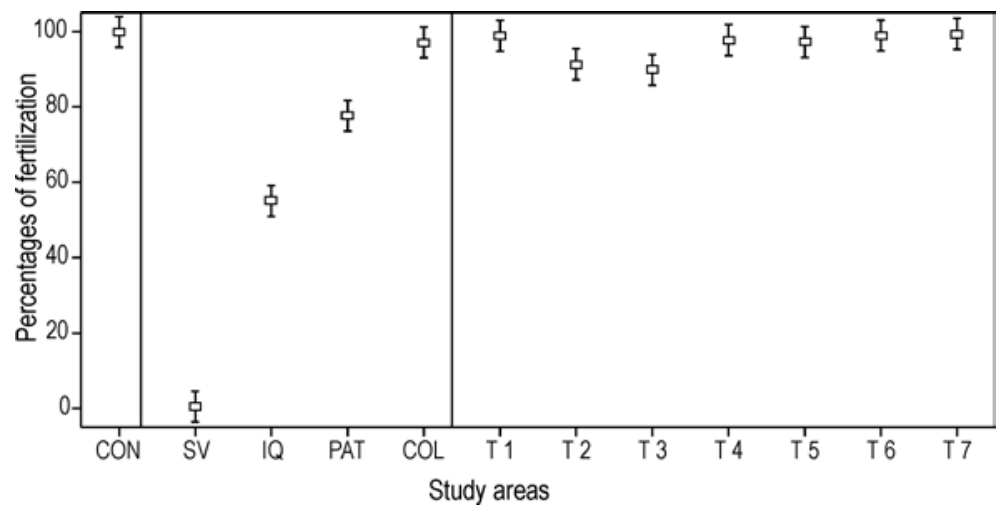

Figure 2. Comparative chart showing mean percentages of eggs fertilized in elutriates from test and control (CON) sediments from the ports of San Vicente (SV), Iquique (IQ), Patache (PAT), and Coliumo (COL, reference sector). Information from Aguirre (2004) and sections in the present study (T1 to T7).

should include assays with organisms that represent different levels of the trophic chain (Duffus, 1983; Van Gestel et al., 2001).

Finally, another element that should be kept in mind in terms of the results obtained herein is that the CIMAR 10 Fiordos sections were designed to detect mesoscale alterations, expecting to find evidence of alterations or spatial gradients from the sources of origin towards the center of the fjords, channels, and major basins of neighboring fjords. The results obtained on this scale do not indicate evidence of alterations and, therefore, the impact of the aquaculture activities could be more local than the spatial coverage of this study. However, the topographic characteristics of the zone (i.e., restricted circulation zones, deep basins) and the results of the chemical characteristics of the near-bottom water (i.e., low dissolved oxygen $\leq 3.5 \mathrm{~mL} \cdot \mathrm{L}^{-1}$ ) and the sediments (i.e., total organic matter $\approx 6.5 \%$ ) correspond to restricted systems with high sedimentation and important sources of natural organic matter (i.e., autochthonous productivity), added to the allochthonous material introduced by rivers and anthropogenic activities (cities, aquaculture), which correspond to zones of high environmental risk.

\section{ACKNOWLEDGEMENTS}

The authors would like to thank the Ministry of Finance for financing this research through the Comité Oceanográfico Nacional, Project CONA-C10F 04-15.

\section{REFERENCES}

Aguirre, G. 2004. Análisis de la toxicidad de sedimentos de puertos de la I y VIII Región de Chile. Tesis de Biología Marina, Universidad Arturo Prat, Iquique, $111 \mathrm{pp}$.

Ahumada, R. 1998. Metales traza ( $\mathrm{Ba}, \mathrm{Cd}, \mathrm{Co}, \mathrm{Cr}$, $\mathrm{Cu}, \mathrm{Ni}, \mathrm{Pb}, \mathrm{V}$ y Zn) en los sedimentos del seno Aysén: línea base y alteraciones ambientales. Cienc. Tecnol. Mar, 21: 75-88.

Alvial, A. 1993. Una aproximación al impacto ambiental de la acuicultura. Aquanoticias Internacional, 16: 21-27.

Arévalo, V., F. Inda, E. Bay-Schmith \& A. Larraín. 2001. Bioensayo de fertilización con erizo de mar (Arbacia spatuligera) para fiscalizar la maniobra de recambio de lastre limpio en los buques. Cienc. Tecnol. Mar, 24: 61-69.

Altamirano-Chovar, C., A. Rudolph \& R. Sepúlveda. 2006. Differential sensitivity to varying degrees of human influence in juvenile Semimytilus algosus (Gould, 1950) (Mollusca: Mytilidae), from four coastal sities in South-Central Chile. Bull. Environ. Contam. Toxicol., 77: 2-10.

Amin, O. \& L. Comoglio. 2002. Toxicidad del petróleo diesel en el primer estadio larval de la centolla (Lithodes santolla) y del centollón (Paralomis granulosa). Rev. Biol. Mar. Oceanog., 37(2): 139-144.

Birch, G.F., S.E Taylor \& C. Mattai. 2001. Smallscale spatial and temporal variance in the concentration of heavy metals in aquatic sediments: a review and some new concepts. Environ. Pollut., 113: 357-372. 
Buschmann, A. 2005. Efectos ambientales de la acuicultura. Oceana, 19: 38- 41.

Byers, Sch., C.E.L. Mills \& P.L. Steward. 1978. A comparison of methods of determining organic carbon in marine sediments with suggestions for a standard method. Hydrobiologia, 58(1): 43-47.

Cairns, J. \& J. Pratt. 1989. The scientific basis of bioassays. Hydrobiologia, 188/189: 1-20.

Carpenter, J.H. 1965. The Chesapeake Bay Institute technique for the Winkler dissolved oxygen method. Limnol. Oceanogr., 10: 141-143.

Clavert, S., R. Bustin \& E. Ingall. 1996. Influence of water column anoxia and sediment supply on the burial and preservation of organic carbon in marine shales. Geochim. Cosmochim. Acta, 60(9): 1577-1593.

Chapman, P.M. 1995. Bioassay testing for Australia as part of water quality assessment programmes. Aust. J. Ecol., 20: 7-19.

Chou, C., L. Paon, J. Moffatt \& T. King. 2003. Selection of bioindicators for monitoring marine environmental quality in bay of Fundy, Atlantic Canada. Mar. Pollut. Bull., 46: 756-762.

Colombo, J.C., N. Silverberg \& J.N. Gearing. 1996. Biochemistry of organic matter in the Laurentian Trough, II. Bulk composition of the sediments and relative reactivity of mayor components during early diagenesis. Mar. Chem., 51: 295-314.

Dinnel, P.A. \& Q.J. Strober. 1985. Methodology and analysis of sea urchin embryo bioassays. Fisheries Research Institute. University of Washington, Seattle W.A., Circular 85: 319 pp.

Duffus, J. 1983. Toxicología ambiental. Ediciones Omega, Barcelona, 173 pp.

Elderfield, H. 1978. Chemical variability in estuaries. In: Biochemistry of estuarine sediment proceedings of a UNESCO/ SCOR Workshop, Bélgica, December, 1976, 293 pp.

Finney, D.J. 1971. Probit analysis. Cambridge University Press, Cambridge, 333 pp.

Fuentes-Ríos, D., R. Orrego, A. Rudolph, G. Mendoza, J.F. Gavilán \& R. Barra. 2005. EROD activity and biliary fluorescence in Schroederichthys chilensis (Guichenot 1848): Biomarkers of PAH exposure in coastal environments of the Pacific Ocean. Chemosphere, 61: 192-199.

Gulley, D.D., A.M. Boelter \& H.L. Bergman. 1988. Toxstat 2.1. Fish physiology and toxicology laboratory. Department of Zoology and Physiology, University of Wyoming, WY, 213 pp.
Hagerman, L., A.B. Josefson \& J.N. Jensen. 1996. Benthic macrofauna and demersal fish. In: B.B. Jorgensen \& K. Richardson (eds.). Eutrophication in coastal ecosystems. Coast. Estuar. Stud., 52: 155-178.

Hites, R.A., J.A. Foran, D.O. Carpenter, M.C. Hamilton, B.A. Knuth \& S.J. Schwager. 2004. Global assessment of organic contaminants in farmed salmon. Science, 303: 226-229.

Kast-Hutchenson, K., C.V. Rider \& G.A. LeBlanc. 2001. The fungicide propiconazole interferes with embryonic development of the crustacean Daphnia magna. Environ. Toxicol. Chem., 20(3): 502-509.

Kelly, L., J. Stellwagen \& A. Bergheim. 1996. Waste loading from a fresh-water Atlantic salmon farm in Scotland. Water Res. Bull., 32: 1017-1025.

Larraín, A., A. Riveros, J. Silva \& E. Bay-Schmith. 1999. Toxicity of metals and pesticides using the sperm cell bioassay with the sea urchin Arbacia spatuligera. Bull. Environ. Contam. Toxicol., 62: 749-757.

Lopes, T.J. \& E. Furlong. 2001. Occurrence and potential adverse effects of semivolatile organic compounds in streambed sediment, United States 1992-1995. Environ. Toxicol. Chem., 20(4): 727737.

Monteiro, P.M.S. \& A.N. Roychoudhury. 2005. Spatial characteristics of sediment trace metals in an eastern boundary upwelling retention area (St. Helena Bay, South Africa): A hydrodynamic-biological pump hypothesis. Estuar. Coast. Shelf Sci., 65: 123-134.

National Oceanographic Data Center (NODC). 1994. World ocean atlas 1994. CD-ROM data sets. U.S. Department of Commerce. National Oceanic and Atmospheric Administration, National Oceanographic Data Center, Ocean Climate Laboratory, Washington, D.C.

Ponce-Vélez, G. \& A.V. Botello, 1991. Aspectos geoquímicos y contaminación por metales pesados en la laguna de términos, Campeche. Hydrobiologica, 1(2): 1-10.

Riveros, A., M. Zúñiga, A. Larraín \& J. Becerra. 1996. Relationships between fertilization of Southeastern Pacific sea urchin Arbacia spatuligera and environmental variables in polluted coastal waters. Mar. Ecol. Progr. Ser., 134: 159-169.

Rudolph, A., C. Franco, J. Becerra, A. Barros \& R. Ahumada. 2002. Análisis de materia orgánica e hidrocarburos aromáticos policíclicos en sedimentos de Bahía Concepción. Bol. Soc. Chil. Quím., 47(4): 403-410. 
Servicio Nacional de Pesca (SERNAPESCA). 2004. Anuario Estadístico de Pesca. Ministerio de Economía y Energía. www.sernapesca.cl.

Silva, J., A. Larraín, E. Bay-Schmith \& R. Roa. 2004. Feeding-regime experiments to enhance gamete production in the carnivorous sea urchin Arbacia spatuligera. Aquaculture, 231: 279-291.

Silva, N. \& C. Calvete. 2002. Características oceanográficas físicas y químicas de canales australes chilenos entre el golfo de Penas y el estrecho de Magallanes (Crucero CIMAR 2 Fiordos). Cienc. Tecnol. Mar, 25(1): 23-88.

Silva, N. \& R. Prego. 2002. Carbon and nitrogen spatial segregation and stoichiometry in the surface sediments of southern Chilean inlets $\left(41^{\circ}-56^{\circ} \mathrm{S}\right)$. Estuar. Coast. Shelf Sci., 55: 763-775.

Silva, N., C. Calvete \& H. Sievers. 1997. Características oceanográficas físicas y químicas de canales australes chilenos entre Puerto Montt y laguna San Rafael. Cienc. Tecnol. Mar, 20: 23-106.

Silva, N., C. Calvete \& H. Sievers. 1998a. Masas de agua y circulación general para algunos canales australes entre Puerto Montt y laguna San Rafael. Chile (Crucero CIMAR-Fiordo I ). Cienc. Tecnol. Mar, 21: 17-48.

Silva, N., J. Maturana, J.I. Sepúlveda \& R. Ahumada. 1998b. Materia orgánica, $\mathrm{C}$ y N, su distribución y estequiometría en sedimentos superficiales de la región norte de los fiordos y canales australes de Chile. Cienc. Tecnol. Mar, 21: 49-74.

StatSoft. Inc. 2001. Statistica (data analysis software system) version 6. www.statsoft.com.

Received: 5 July 2006; Accepted: 31 August 2007
Stumm, W. \& J.J. Morgan. 1981. Aquatic chemistry: an introduction emphasizing chemical equilibrium in natural water. John Wiley \& Sons, New York, $780 \mathrm{pp}$.

U.S. Environmental Protection Agency (USEPA). 1988. Short-term methods for estimating the chronic toxicity of effluents and receiving waters to marine and estuarine organisms. Office of Research and Development, U.S. Environmental Protection Agency. Washington D.C. 206460. EPA/600/4-87-028.

Valdenegro, A. \& N. Silva. 2003. Caracterización física y química de la zona de canales y fiordos australes de Chile entre el estrecho de Magallanes y cabo de Hornos (CIMAR 3 Fiordos). Cienc. Tecnol. Mar, 26(2): 19-60.

Van Gestel, C.A., J.J. van der Waarde, J.G. Derksen, E.E. Van Hoek, M.F. Veul, S. Bouwens, B. Rusch, R. Kronenburg \& G.N. Stokman. 2001. The use of acute and chronic bioassays to determine the ecological risk and bioremediation efficiency of oil-polluted soils. Environ. Toxicol. Chem., 20(7): 1438-1449.

Wong D.C.L., E.Y. Chai, K.K. Chiu \& P.B. Dorm. 1999. Prediction of ecotoxicology of hydrocarboncontaminated soil using physicochemical parameters. Environ. Toxicol. Chem., 18: 2611- 2621.

Zuñiga, M. 1999. Evaluación de la calidad acuática de bahía San Jorge a través de ensayos de toxicidad crónica con gametos del erizo de mar Arbacia spatuligera. Cienc. Tecnol. Mar, 22: 59-74. 